\title{
IMPACT OF MACROECONOMIC INDICATORS ON PUBLIC DEBT OF SLOVAK REPUBLIC
}

\author{
Miroslava KNAPKOVÁ (D ${ }^{*}$, Martin KIABA², Samuel HUDEC ${ }^{3}$ \\ 1, 2 Department of Economics, Faculty of Economics, Matej Bel University, \\ Banská Bystrica, Slovakia \\ ${ }^{3}$ Department of Mathematics, Faculty of Natural Sciences, \\ Matej Bel University, Banská Bystrica, Slovakia
}

Received 25 January 2019; accepted 15 April 2019

\begin{abstract}
The paper focuses on impact of macroeconomic indicators on the development of public debt in Slovakia. The aim of the paper was to identify those macroeconomic indicators which influence the most significantly public debt in Slovakia and to elaborate and verify simple model for public debt prediction. Research was based on the analysis of chosen macroeconomic indicators. Selection of macroeconomic indicators resulted from theoretical knowledge and study of various research papers. Authors used several scientific methods, such as content-causal analysis, comparison, mathematical and statistical methods, including simple linear regression. Macroeconomic indicators, which authors proved to be statistically significant, are GDP growth rate, openness of economy, size of public sector, government bond yields, and unemployment rate. Authors elaborated model of the public debt development in Slovakia by using a simple linear regression model. Regression model was calculated using the data for 1995-2016. Authors confirmed correctness of the model by using data for 2017. Research was limited by the fact, that there are limited data available for analysis (time series of 22 years) because of short existence of independent Slovakia. It will be necessary to continue with the research and to verify correctness of chosen indicators in longer period.
\end{abstract}

Keywords: public debt, macroeconomic indicators, linear regression model, prediction model, Slovakia, short-term period.

JEL Classification: E01, H63, H68.

\section{Introduction}

Budget deficits and high public debts associated with them are current, and without an adequate solution, also future major problems of the world's economies. High public debt makes the conditions for effective fiscal policy more difficult and, at the same time, causes difficulties in seeking financial resources on the capital markets. The worldwide economic crisis has caused that public debt began to rise sharply in most countries. It leads to various measures

${ }^{*}$ Corresponding author. E-mail: miroslava.knapkova@umb.sk 
to reduce public debt, to restore economic growth and to recover national economies. However, the threat of high public debt and its negative consequences are still up to date.

There are various factors behind the development of public debt. They vary from historical factors (Stasavage, 2003; Page, 2018; D’Erasmo \& Mendoza, 2018), through political (Di Bartolomeo et al., 2018; Ono \& Uchida, 2018), to economic factors (Poghosyan, 2018; Chen, Yao, $\mathrm{Hu}, \& \mathrm{Lin}, 2017)$. Given the complexity and range of the issue, from several factors influencing public debt in the research, authors have selected only group of macroeconomic indicators. The paper addresses the issue of the dependence and impact of macroeconomic indicators on public debt.

The interdependence of the development of public finances and macroeconomic indicators was already confirmed by various scientific studies (Knedlik \& Schweinitz, 2012; Savona \& Vezzoli, 2015; Cournède, 2010; Lammam \& MacIntyre, 2016; Neck, Blueschke \& Weyerstrass, 2012; and others). The research studies were conducted either by individual authors or by scientific teams within international organizations, such as The Organization for Economic Cooperation and Development (further in the text "OECD"), the International Monetary Fund (further in the text "IMF"), the European Central Bank (further in the text "ECB") and the European Commission (further in the text "EC").

The aim of the paper is to identify those macroeconomic indicators which influence most significantly public debt in Slovakia and to elaborate and verify simple model for public debt prediction in Slovakia. In the paper, authors examine various macroeconomic indicators and their impacts on the public debt in Slovakia. When considering relationship between the macroeconomic indicators and public debts, most of the researchers analyzed influence of foreign direct investments, inflation, unemployment rates, government spending, labor productivity, government bonds, and interest rates on public debt. Researchers have also used macroeconomic indicators to construct various models for predicting public debt and its trends. The study offers unique approach to identify the most significant indicators from various macroeconomic areas, including openness of the economy.

This paper is organized in five sections. The theoretical framework of the research is proposed in Section 1. It focused on theoretical and field researches of European and world economists, which describe interrelation between the public debt and various indicators (macroeconomic as well as other factors). According to the studies, the most reliable indicators are political factors, such as political decisions and democracy, gross domestic product and economic growth, inflation, unemployment, and government bonds. The methodology of the research is described in Section 2. Authors analyzed situation in Slovakia from 1995 to 2016 and collect relevant macroeconomic indicators for this period. Consequently, authors used linear regression model to identify relationship between the public debt and macroeconomic indicators. Creation of the model, including steps of its creation and verification of the correctness of the model, are presented in Section 3. At first, authors described process of creating the model. After that authors verified applicability of the model by using the Q - Q plot, homoscedasticity, and coefficient of variance. Prediction of the public debt in Slovakia for year 2017 is available in Section 4. Finally, the research implications, research limitations and future directions for continuing research are discussed. 


\section{Theoretical framework of the research}

This paper focuses primarily on the relationship between the debt development in public finances and the development of the overall macroeconomic environment. Apart from the macroeconomics, there are also other factors influencing debt indicators. Authors could mention mostly exogenous non-economic factors, such as unfavorable natural conditions, natural disasters, military conflicts, epidemics, global environmental problems, migration, demographic, and political factors affecting deficit and public debt. Some researches focusing on political factors showed that, both in the short term and long term, it is possible to rank these factors among the most important ones influencing the size of the public debt. In the last 30 years, numerous researches in this area were conducted within the European Union, OECD and Latin America member states. Particular research works are interlinked. In some cases, they complement each other, in other cases, they confront one another. Based on the research papers, it is possible to point to some common and interesting conclusions concerning the impact of political decisions on public spending, deficits and ultimately public debts. Persson, Roland and Tabellini (2007), and Milesi-Ferretti, Perotti and Rostagno (2002), agreed that government spending is higher if the government's political forces are distributed proportionally in comparison with government spending under the majority government. According to their findings, if the proportional government transforms into a majority one, government spending would be reduced. Roubini and Sachs (1989) and Vučkovic and Sertic (2013) agreed that decisions made by the fragmented government result in higher budget deficit and in overall public debt. Eusepi and Wagner (2017) focused on the comparison of public debt in democratic states and monarchies. They summed up that it is not possible to avoid public debt in democratic states, while in monarchies public debt could be eliminated. Although the political factors significantly affect the public finances of the state, we abstract from them in the research and focus only on the macroeconomic factors which affect the deficit and consequently the public debt. Study by Challe, Charpe, Ernst and Ragot (2011) also focuses on government spending. Governments are trying to boost household consumption during the economic downturn, through financial support for the unemployed. Unemployment benefits are dampening the impact of employment decline and thus declining household consumption. However, this measure increases government spending, which is often reflected in the increase in public debt. Mazúrová and Kollár (2015) focused on the development and structure of government spending of Slovak Republic, in the period between 1997 and 2011. Their findings showed that the proportion of government spending to GDP ratio on infrastructure in these years in Slovakia was higher than the average in the European Union. However, they proved that government spending stimulates economic growth even during the crisis. Berggren and Bjornskov (2019) pointed out that regulation of economy (such as regulation of labor, business and credit) have significant influence on public debt. Based on the empirical analysis covering up to 67 countries during the period 1975-2010, they confirmed that regulatory freedom, especially with respect to credit availability, reduces debt accumulation (it is even more significant during the policy stability and credibility, and when governments have right-wing ideologies). 
In the following part of the paper, authors present fundamental findings of national and foreign studies, which focused on the relationship between the various macroeconomic indicators and public debts, as well as on models for public debt prediction. In the research, authors focus on the impact of macroeconomic indicators on public debt. However, it is not possible without considering the opposite relationship, mutual interconnection of public debt and economic growth. Checherita-Westphal and Rother (2012) analyzed the non-linear effect of public debt on GDP growth in 12 countries of the euro area. Their results showed that the function displaying a relationship between public debt and GDP growth rate has a concave shape with a turnover point at $90 \%$ to $100 \%$ of public debt ratio to GDP. This conclusion is supported by the study of Reinhart and Rogoff (2010). They monitored public debt and GDP growth in 44 countries in the period of almost 200 years. The results proved that public debt negatively affects the growth of GDP when the level of indebtedness is above $90 \%$ of GDP. However, another analysis carried out by Caner, Grennes and Koehler-Geib (2010) on 101 countries within the period 1980-2008 showed a different debt value, which has a negative impact on economic growth. According to this study, the critical value of public debt is at the level of $77 \%$ of GDP. Public debt that goes beyond this limit has a negative impact on GDP growth. The same result was presented also by Nayak and Pandit (2015). Gomez-Puig and Sosvilla-Rivero (2018) analysed influence of the public debt on economic area in euro area in the period of 1961-2013. They pointed out that public debt always has a negative impact on the long-run performance of euro area member states, whilst its short-run effect may be positive depending on the country. Interaction between the economic growth, public debt and political power (namely old and young voters) was analysed by Real, Katsuyuki and Tetsuo (2018). Their study showed that increased political power of old voters lowers economic growth, which eventually leads to higher public debt.

While many researchers try to find a universal threshold from which the negative impact of debt growth is evident, other researchers proclaim that threshold is different in various countries. On the other side, Pescatori, Sandri and Simon (2014) argued that there is no evidence of a specific debt threshold that would divide the amount of debt into "good" and "bad", the one, which should have positive or negative impact on growth. Baum, ChecheritaWestphal and Rother (2012) also confirmed similar findings. Their results indicated that the short-term impact of the public debt on GDP growth is positive, but it declines almost to zero and loses importance if the ratio of public debt to GDP exceeds $67 \%$. This result was applicable for most of applications their monitored, in dynamic and non-dynamic models.

Some authors also confirmed the negative impact of public debt on private consumption. The non-linear effects of public debt on private consumption were, for example, the subjectmatter of Choa and Rhee (2013). They conducted research in 16 OECD countries in the period of years 1983-2011. Their findings confirmed importance of a threshold, namely $83.7 \%$ of public debt on GDP. Similar threshold was confirmed also by Berben and Brosens (2007), and Reinhart and Rogoff (2010). Model of Ambler, Bouakez and Cardia (2017) pointed out, that an increase in public spending is associated with an increase in private consumption and the real wage. Goedl and Zwick (2018) analysed long-run distribution of Austrian public debt using a Markov chain model of the debt-GDP ratio. Their found out that Austrian fiscal policy is consistent with a stable long-run distribution of the debt-GDP ratio with a value 
close to the $60 \%$ threshold. They also showed that the existence of a stable long-run distribution of the debt-GDP ratio depends on a continuing tendency of fiscal policy to reduce the primary deficit in face of rising debt. Debt to GDP ratio in Spain was a subject-matter of Esteve and Tamarit (2018). They investigated the long-run relationship between public debt and economic growth in the Spanish economy for the period 1851-2013. They found some support for a negative relationship between public debt and economic growth, however, they did not confirm clear evidence of a debt threshold.

Many studies investigate the macroeconomic imbalance that leads directly to the debt crisis. Several authors point to the negative effects of the debt itself, its disproportionate increase associated with other economic imbalances, in particular. However, this fact does not automatically predict the debt crisis. Therefore, it is important to predict future crisis, but also to predict the debt development in general and possibly also the extent of debt growth. For this purpose, team of Sinha, Arora and Bansal (2011) elaborated a multiple regression model for forecasting public debt development. It was designed separately for low-income countries and for high-income (or more advanced) countries. They pointed out that the impact of macroeconomic indicators is different in countries with different economic levels of development. There are differences, for example, in the effects of FDI, which have a greater impact on the indebtedness of the countries that belong to the middle-income group of countries compared to high-income countries. The second difference is that inflation and interest rates are important indicators for the middle-income group of countries, but not for high-income countries. The high variability of any change in interest rates or inflation thus has a significant impact on government borrowing costs. Dawood, Horsewood and Strobel (2017) used several crisis variables to develop powerful dynamic-recursive technique for debt crises forecasting.

Many other researchers have shown that the relationship between public debt and inflation has a reciprocal dependence. Dependence of public debt and inflation was empirically verified, for example, by the study of Reinhart and Rogoff (2010). They carried research in 44 countries over a 200 -year period, and they monitored dependency between inflation and public debt. According to their research, public debt and inflation have a two-sided dependency. Kwon, McFarlane and Robinson (2006) obtained a similar result. The results of their regression showed that the debt increase is strongly associated with high inflation. However, this has been proved only in developing countries. Aizenman and Marion (2009) modelled the impact of inflation on public debt. According to them, the possibility of reducing debt through inflation is nothing new and this method is applicable. The interdependence of these two indicators is obvious, as well as their mutual influence. Their model predicts that the annual inflation rate of $6 \%$ may reduce debt by up to $20 \%$ over the course of four years. It goes without saying that the simulation took place at specific levels of indebtedness and that the output parameters would be different for another input. Akitoby, Binder and Komatsuzaki (2017) studed impact of low or high inflation on the public debt-to-GDP ratio in the G-7 countries. Their findings show that if inflation were to fall to zero for five years, the average net debt-to-GDP ratio would increase by about 5 percentage points during that period. In contrast, raising inflation to 6 percent for the next five years would reduce the average net debtto- GDP ratio by about 11 percentage points. They also confirmed that higher inflation 
could help reduce the public debt-to- GDP ratio in advanced economies. The interdependence between the inflation and public debt is analysed also in study of Ferrari (2018). His findings showed that it is optimal for the government to adopt a policy that keeps the debtto-GDP ratio under an inflationdependent ceiling. Bohn (2019) published research based on 25 years data focusing on link between seigniorage finance and deficit finance when a country is politically unstable. His findings showed a potential negative correlation between them.

The indicator of unemployment rates is another factor that can be assumed to be linked to public debt. For example, the research study by Horváthová, Horváth, Gazda and Kubák (2012), which focuses on the interdependence of unemployment and public debt, shows that unemployment has a negative impact on public debt. The reason is that rising unemployment can cause tax revenue cuts. The research study by Neck, Blueschke and Weyerstrass (2012) deals also with the issue of unemployment. They results show that it is slightly better for the economy to boost GDP growth and take steps to reduce unemployment even though it will temporarily be at the expense of higher indebtedness.

Another macroeconomic indicator influencing public debt is labor productivity. As the study by Blavy (2006) states, there is interdependence between the level of public debt and productivity. Analysis of the sample of 35 developing countries has shown that rising indebtedness has the effect of reducing the country's labor productivity growth rate. High level of indebtedness interfere with the correct capital allocation in the country by increasing uncertainty for investors and it also leads to smaller number of positive externalities resulting from public investment. On a sample of 20 OECD economies, Salotti and Trecroci (2012) conducted an analysis in 1970-2009. Their results also confirmed that the growth of public sector indebtedness is associated with a lower rate of productivity growth. Lammam and MacIntyre (2016) state that in the long run, government debt may negatively affect economic growth and prosperity. A high and growing public debt can lead to increase interest rates. Subsequently, this leads to higher borrowing costs in the private sector, which discourages the company from capital investment - the main driving force of productivity. Oulton and Sebastiá-Barriel (2017) analysed influence of the financial crisis interlinked with public debt on the labour productivity. On the case of 61 countries in the period of 1954-2010, they elaborated a model to estimate short-run and a long-run effects of the crisis on the growth rate of labor productivity. They also pointed out, that effects of crisis are larger in developing than in developed countries.

The last indicator, which analyses several studies in relation to public debt, is the yield on government bonds. As the theory states, the relationship between interest rate on government bonds and fiscal responsibility can be seen from two perspectives. Rising interest rates can naturally increase public debt on the one hand, but on the other hand, it can work the other way, as at high interest rates, governments are forced rather exercise restrictive fiscal policy than borrowing and paying high interest rates (Horváthová et al., 2012). Furceri and Mourougane (2010) have studied the effects of fiscal policy using the sample of euro area countries. The outcomes of their model show that increasing the deficit-to-GDP ratio by one percentage point increases the spread between government bond yields and short-term rates by 0.25 percentage points. In his study, Cournède (2010) examines the change in yields on government bonds in relation to public debt. A very high ratio of government debt to GDP 
can push up interest rates on government bonds, which subsequently affects the cost of financing for businesses. The transmission mechanism of interest rate increases on government bonds is reflected in corporate loans, usually not in proportion one to one but slightly less.

When considering relationship between the macroeconomic indicators and public debts, most of the researchers analyzed influence of foreign direct investments, inflation, unemployment rates, government spending, labor productivity, government bonds, and interest rates on public debt. Researchers have also used macroeconomic indicators to construct various models for predicting public debt and its trends.

One of the most comprehensive analyses of the dependence of public debt on macroeconomic indicators was elaborated by Knedlik and Schweinitz (2012). They analyzed four frequently used models of the European Commission (2010), the European Central Bank (ECB, 2010), the German Ministry of Economics and Technology (Bundesministerium für Wirtschaft und Energie - BMWi, 2010) and Heise (2011). Apart from evaluating all four models, the authors also introduced their own composite indicator. When compiling it, they came out of the belief that the model should be composed of the highest possible number of indicators. The evaluation showed that the weakest results were attained using the European Commission model. The Heise's model was relatively good and the most accurate results were achieved using a composite indicator. This may support the assumption that a comprehensive indicator is the most appropriate to achieve the most accurate prediction of the public debt.

Savona and Vezzoli (2015) devoted their research to the creation of the debt-crisis forecasting model. They created a model that they used to analyze the situation in the group of developing countries and in the PIGS countries between years 1975 and 2010. Based on this analysis, the main factors, that can be used to predict long-term crises, are the liquidity of the economy (the ratio of short-term debt to reserves), bonds interest rates, GDP growth, undervaluation of currency and political developments in the country.

Csortos and Szalai (2014) focused on forecasting macroeconomic and financial inequalities. They used the EWS (Early Warning System) methodology for a group of ten Central and Eastern European countries to predict their macroeconomic and financial imbalances. Research of Islami and Kurz-Kim (2014) was initiated by problems in the banking sector and by the need to find a more appropriate predictive tool for forecasting financial stress and financial crises. Their study showed that indicator "implied stock market volatility", which has been used in the past for predicting crises in the banking sector, is inadequate for predicting problems in the real economy. Authors therefore proposed to use a composite indicator of financial stress which will consist of several monitored variables.

Even there are many researches focusing on the different aspects and indicators influencing public debt, there is no complex study focusing on the public debt in Slovakia or surrounding countries. Slovakia, as a small open economy, developing from socialistic to transitional and finally to market economy, has many specific features comparing to west countries. Lack of continuity, relatively short period of available data (Slovakia as independent country exists from 1993), and previous instability in public finances cause, that public debt models (which describe or eventually predict public debt) vary and change depending on the choosing variables influencing public debt. Intention of this research is to identify those macroeconomic indicators (without considering other factors) that influence public debt in Slovakia most significantly. 


\section{Research methodology}

To achieve the goal of the research, authors used several methodological approaches. The basis of the research was the content-causal analysis of the theoretical knowledge and practical field researches. Regarding the theoretical approaches (presented in previous chapter of this paper), authors defined macroeconomic indicators that they included in the database for analytical processing by mathematical and statistical methods. Based on a review of a set of studies that addressed multiple macroeconomic indicators, authors decided to use following indicators for this empirical research: GDP growth (supported by Checherita-Westphal \& Rother, 2012; Caner et al., 2010; Nayak \& Pandit, 2015; Gomez-Puig \& Sosvilla-Rivero, 2018; Real et al., 2018), inflation (supported by Reinhart \& Rogoff, 2010; Kwon et al., 2006; Aizenman \& Marion, 2009; Akitoby et al., 2017; Bohn, 2019), unemployment (Horváthová et al., 2012; Neck et al., 2012), labor productivity (Blavy, 2006; Salotti \& Trecroci, 2012; Lammam \& MacIntyre, 2016; Oulton \& Sebastiá-Barriel, 2017), public sector size, expressed as government spending (Challe et al., 2011; Persson, Roland, \& Tabellini, 2007; Milesi-Ferretti et al., 2002; Eusepi \& Wagner, 2017), and government bond yields (Horváthová et al., 2012; Furceri \& Mourougane, 2010; Cournède, 2010). Slovakia, as a small economy, belongs between the most open economies in European Union. That is why we decided to consider openness of economy as another macroeconomic indicator which could influence public debt in Slovakia.

Authors analyzed period from 1995 to 2016. Since Slovakia as independent country exists only from January 1993, it is not adequate to use data from previous period into account (there was a strong influence of other than economic factors, such as political, historical, etc.). In 1995, stabilization after transitional period was visible in many areas. According to Národná stratégia trvalo udržatelného rozvoja SR (2001), from the beginning of existence up to 1994, Slovakia belonged between the countries with relatively lowest rate of foreign debt. It significantly changed in 1995. In 1995, inflation rate in Slovakia was for the first time under 10\%. From 1995, the GDP started to grow, all components of domestic demand had increased, and labor productivity had grown. That is why authors considered year 1995 as first year of the analysis.

Authors used linear regression to model relationship between the public debt and various macroeconomic indicators. By defining the explained variable (public debt, expressed as share of public debt on GDP in percentage) and explanatory variables (GDP growth, inflation, unemployment rate, openness of economy, public sector size, government bond yields, and labor productivity), authors created preconditions for the use of statistical analysis leading to the creation of a linear regression model. The linear regression model gives us the opportunity to specify the interrelationships between several variables. The basic matrix contains one dependent variable, which is the share of public debt on GDP in percentage. The set of explanatory variables consists of seven macroeconomic indicators, on which, as authors assume, public debt is dependent. All statistical computations leading to the creation of a linear regression model were done in program $\mathrm{R}$.

The linear regression model must meet certain assumptions in order to predict the development of public debt. It is above all the normality of observation, the homoscedasticity of data and the appropriate value of variance coefficient. To verify that the data meet normality 
assumption, authors used a quantile-quantile graph (Q-Q plot). A Q-Q plot compares the distribution of empirical data to a normal distribution by plotting the quantiles of empirical data on vertical axes against the quantiles of a normal distribution on horizontal axes.

To verify the stability of the model, authors determined whether the variance of the deviations of the empirical and model values was homoscedastic. The homoscedasticity means that the variance around the regression line is the same for all values of the independent variables. A model plot that meets the homoscedasticity condition displays residual variations as points randomly spaced around zero in a given range. If the plot shows residual variations as points that are differently scattered, it is so called heteroscedasticity.

The accuracy of the linear regression model can be verified by the coefficient of determination $R^{2}$. This coefficient indicates how well terms (data points) fit a curve or line. For more explanatory variables, it is advisable to use adjusted $R^{2}$. In this case, the coefficient of determination also indicates how well terms fit a curve or line, but adjusts for the number of explanatory variables $(n)$ in the model:

$$
R_{a d j}^{2}=1-\left(1-R^{2}\right) \frac{n-1}{n-k-1} .
$$

Adjusted $R^{2}$ will always be less than or equal to $R^{2}$. The adjusted $R^{2}$ tells the percentage of variation explained by only the independent variables that actually affect the dependent variable.

\section{Creation of the model}

All inputs variables that authors used in the research, it means inflation, unemployment, openness of the economy, labour productivity, GDP growth, the size of the public sector, government bond yields, and public debt to GDP, are displayed in Table 1.

Table 1. Macroeconomic indicators for the period 1995 to 2017 (in \%) (source: own data processing from Eurostat, n.d.)

\begin{tabular}{|c|c|c|c|c|c|c|c|c|}
\hline \multirow{2}{*}{ Year } & \multirow{2}{*}{$\begin{array}{c}\text { Public } \\
\text { debt }\end{array}$} & $\begin{array}{c}\text { GDP } \\
\text { growth }\end{array}$ & $\begin{array}{c}\text { Infla- } \\
\text { tion }\end{array}$ & $\begin{array}{c}\text { Unemploy- } \\
\text { ment }\end{array}$ & $\begin{array}{c}\text { Openness } \\
\text { of economy }\end{array}$ & $\begin{array}{c}\text { Public } \\
\text { sector }\end{array}$ & $\begin{array}{c}\text { Government } \\
\text { bond yield }\end{array}$ & $\begin{array}{c}\text { Labour } \\
\text { prod. }\end{array}$ \\
\hline & $x_{1}$ & $x_{2}$ & $x_{3}$ & $x_{4}$ & $x_{5}$ & $x_{6}$ & $x_{7}$ \\
\hline 1995 & 21.7 & 6.8 & 5.8 & 12.7 & 91 & 48.2 & 8 & 4.6 \\
\hline 1996 & 30.5 & 6.8 & 5.8 & 12.7 & 92.4 & 53.1 & 8 & 4.6 \\
\hline 1997 & 33 & 6.1 & 6 & 12.7 & 95.9 & 48.4 & 8 & 7.2 \\
\hline 1998 & 33.9 & 4 & 6.7 & 12.7 & 90.6 & 45.6 & 8 & 4.5 \\
\hline 1999 & 47.1 & -0.2 & 10.4 & 16.5 & 92.9 & 47.9 & 8 & 2.4 \\
\hline 2000 & 49.6 & 1.2 & 12.2 & 18.9 & 98.2 & 52 & 8 & 3.2 \\
\hline 2001 & 48.3 & 3.3 & 7.2 & 19.5 & 109.4 & 44.4 & 8 & 2.7 \\
\hline 2002 & 42.9 & 4.5 & 3.5 & 18.8 & 111.3 & 45.1 & 6.9 & 4.4 \\
\hline 2003 & 41.6 & 5.4 & 8.4 & 17.7 & 119 & 39.9 & 5 & 4.3 \\
\hline
\end{tabular}


End of Table 1

\begin{tabular}{|c|c|c|c|c|c|c|c|c|}
\hline \multirow{2}{*}{ Year } & \multirow{2}{*}{$\begin{array}{c}\text { Public } \\
\text { debt }\end{array}$} & $\begin{array}{c}\text { GDP } \\
\text { growth }\end{array}$ & $\begin{array}{c}\text { Infla- } \\
\text { tion }\end{array}$ & $\begin{array}{c}\text { Unemploy- } \\
\text { ment }\end{array}$ & $\begin{array}{c}\text { Openness } \\
\text { of economy }\end{array}$ & $\begin{array}{c}\text { Public } \\
\text { sector }\end{array}$ & $\begin{array}{c}\text { Government } \\
\text { bond yield }\end{array}$ & $\begin{array}{c}\text { Labour } \\
\text { prod. }\end{array}$ \\
\hline 2004 & 40.6 & 5.3 & 7.5 & 18.4 & 137 & 37.8 & 5 & 5.5 \\
\hline 2005 & 34.1 & 6.8 & 2.8 & 16.4 & 146.5 & 39.8 & 3.5 & 5.1 \\
\hline 2006 & 31 & 8.5 & 4.3 & 13.5 & 163.7 & 38.8 & 4.4 & 6.2 \\
\hline 2007 & 30.1 & 10.8 & 1.9 & 11.2 & 165.3 & 36.3 & 4.5 & 8.5 \\
\hline 2008 & 28.5 & 5.6 & 3.9 & 9.6 & 161.6 & 36.9 & 4.7 & 2.3 \\
\hline 2009 & 36.3 & -5.4 & 0.9 & 12.1 & 140.5 & 44.1 & 4.7 & -3.5 \\
\hline 2010 & 41.2 & 5 & 0.7 & 14.5 & 154.1 & 42.1 & 3.9 & 6.7 \\
\hline 2011 & 43.7 & 2.8 & 4.1 & 13.7 & 166.1 & 40.8 & 4.4 & 1 \\
\hline 2012 & 52.2 & 1.7 & 3.7 & 14 & 173.1 & 40.6 & 4.6 & 1.6 \\
\hline 2013 & 54.7 & 1.5 & 1.5 & 14.2 & 181 & 41.4 & 3.2 & 2.3 \\
\hline 2014 & 53.6 & 2.6 & -0.1 & 13.2 & 183.8 & 42 & 2.1 & 1.1 \\
\hline 2015 & 52.6 & 3.8 & -0.3 & 11.5 & 190 & 45.2 & 0.9 & 1.8 \\
\hline 2016 & 52.5 & 3.3 & -0.5 & 9.7 & 193.1 & 41.5 & 0.5 & 0.9 \\
\hline 2017 & 51.8 & 3.4 & 1.3 & 8.1 & 194.4 & 40.4 & 0.9 & 1.2 \\
\hline
\end{tabular}

The explained variable in the model is the share of public debt on GDP $(y)$ and the explanatory variables are the macroeconomic indicators $\left(x_{1} \ldots x_{7}\right)$.

\subsection{Process of creating model}

To create the model, authors followed following steps:

1. Authors checked each variable (macroeconomic indicator) separately. Authors displayed each variable for the years 1995 to 2016 and analysed correlation of the response to the predictors. According to this analysis, GDP growth, unemployment rate, labour productivity, government bonds yields and openness of the economy, seemed to be the most useful variables for the future regression model (prediction model 1);

2. Authors calculated linear regression model by using all the variables (macroeconomic indicators). By the means of a Q-Q plot and homoscedastic test (residuals vs. fitted values), authors found out, that model with all variables has several deficiencies (prediction model 2). It was also evident that data for the year 2009 are unusual comparing to data from other years. Year 2009 was influenced by economic crisis and recession, that is why most macroeconomic indicators were not developing continuously (in most western economies, economic crisis started in 2008. Slovak economy has been strongly linked with German economy, mostly with the automotive industry, and recession in Germany influenced also recession in Slovakia, however with one-year delay.);

3. Authors used Akaike's information criterion (it compares the quality of a set of statistical models to each other) to compare the prediction model 1 and prediction model 2 
(both models without data for year 2009). According to this selection criterion, prediction model 1 is much more accurate. By the means of Q-Q plot and homoscedastic test, authors verified prediction model 1. It was clear, that data for years 2007 and 2008 were also unusual comparing to the rest of the period. Year 2007 was the year with the highest economic growth, not only in the history of independent Slovakia, but also in comparing to other Central-Europe countries. Year 2008 was the year of the beginning of economic crisis (the biggest impact of economic crisis was visible in 2009 in Slovakia, but year 2008 was also strongly influenced by it). It seems to be logical to exclude all years 2007, 2008, 2009 from the model.

4. To make model clearer and more adequate, authors set intercept on 0 . This is the final model, the most accurate model, according to which public debt in Slovakia is influenced (and dependent on) by 5 macroeconomic indicators: GDP growth, unemployment rate, labour productivity, government bonds yield and openness of the economy. The final estimates of the regression model parameters, that are output from the $\mathrm{R}$ program, are shown in Table 2.

Table 2. Output of processing of indicators from the $\mathrm{R}$ program own data processing in $\mathrm{R}$ program (source: own data processing in R program)

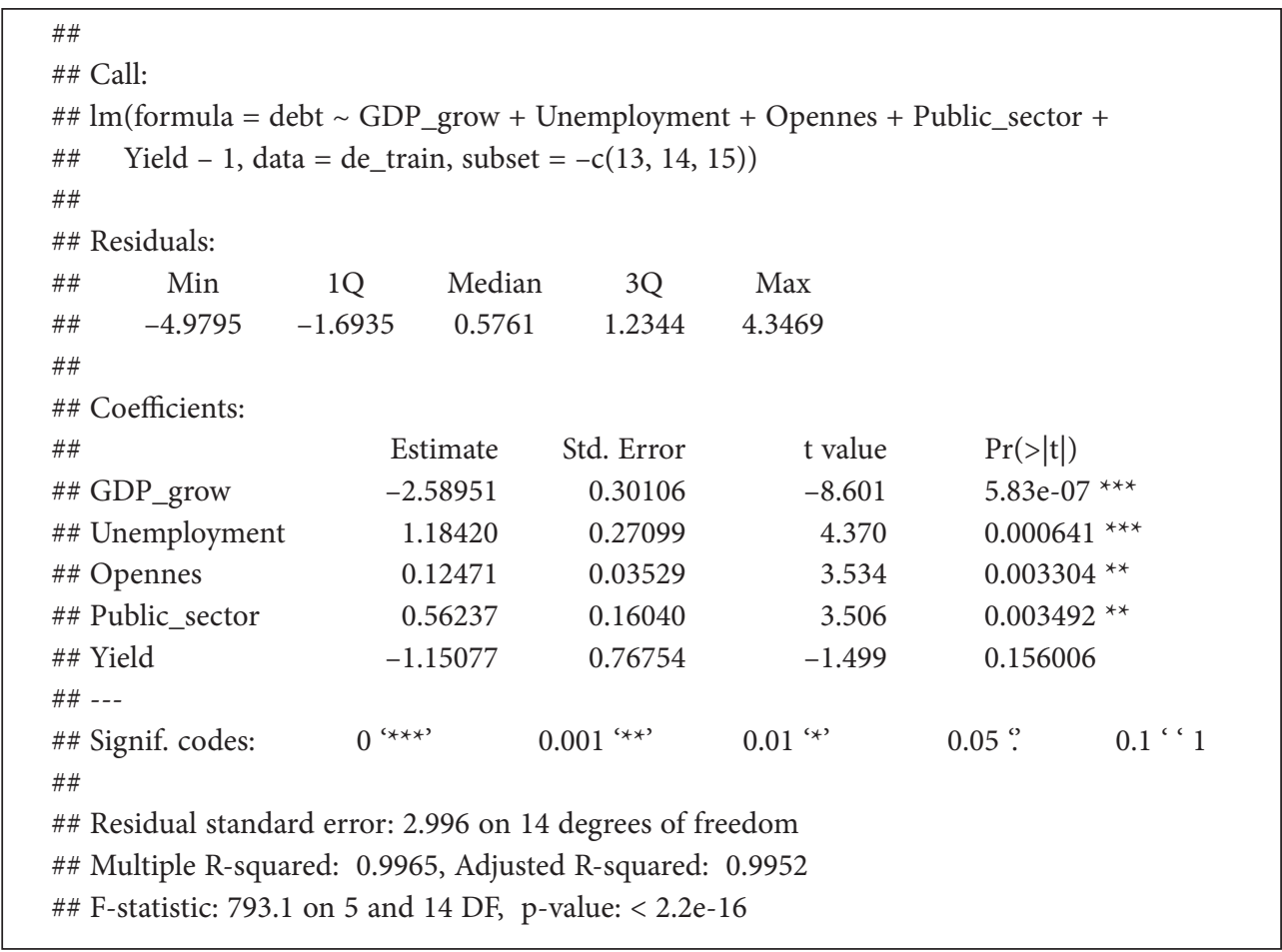

In the contribution, authors present only the variables that showed a significant correlation with the development of the public debt. Therefore, the final linear regression model is formed by only five of the original seven explanatory variables. 
On the basis of the parameters authors confirmed that the gross domestic product growth indicator has the greatest impact on the development of public debt. This indicator has almost twice as much impact as the second most influential indicator, unemployment. The value of growth of the gross domestic product has got a minus sign indicating negative dependence, which means that the gross domestic product growth significantly reduces the debt ratio to GDP. The observed dependence confirms the existing empirical findings and basic assumptions.

The second most influential indicator in the model is the unemployment rate. The value is positive and means that the increase in unemployment leads to an increase in the ratio of public debt to gross domestic product. It is possible to explain this phenomenon in several ways. On one hand due to higher unemployment rate the revenue from tax collection and levies is declining, on the other hand rising unemployment results in increasing social transfers expenditure that are including unemployment benefits. The obtained result reaffirms the theory that explains relationship between unemployment rate and the ratio of public debt to gross domestic product (e.g. Horváthová et al., 2012).

The third most influential indicator is government bond yields. The value is negative, which means that growth of the government bond yields significantly reduces the debt to GDP ratio. It is caused by the fact, that higher government bonds yields lead to more expensive loans for government (it means less available). Less available loans could positively influence total indebtedness of the state and that is why also on the decrease of the public debt.

As for impact intensity, the fourth and fifth indicators are the size of the public sector and the openness of the economy. Both macroeconomic indicators did not appear directly in the models in the past. The size of the public sector is expressed as a percentage of public spending on GDP. The parameter of this indicator has a positive sign, which can be interpreted as follows: If the public sector is growing, the public debt is increasing as well. An increase in the need to finance public goods without sufficient financial resources on the revenue side of the budget puts pressure on the increase in the deficit and consequently in the public debt. It follows that although the theory does not pay much attention to issues of public debt and public sector size, the inclusion of this variable in the model is justified.

The last indicator, the openness of the economy is measured as the ratio of the sum of export and import to the gross domestic product. The impact factor of this indicator is considerably weaker comparing to others. The linear model predicts the openness of the economy as statistically significant factor. The growth of the openness of the economy should theoretically contribute to the increase of indebtedness. Based on general knowledge and authors' subjective approach, this dependence seems not to be so crucial. Without further analysis authors do not attribute an important significance to this parameter, at the present level of knowledge. Authors can accept a possibility that the value of parameter is due to statistical deviation or it results from a model imperfection.

\subsection{Verification of the applicability of the linear regression model}

If a linear regression model is to be suitable to predict the public debt, then it has to fulfill several statistical assumptions. 
The first assumption of the applicability of a linear regression model is normality of observation. To evaluate normality, authors have used the Q - Q plot. The graph shows points, whose coordinates are the values (quantiles) of normal distribution with a mean 0 on the horizontal axis and the distribution of empirical data on the vertical axis. Figure 1 confirms that values show a normal distribution, as the points are located either on or close to the straight line.

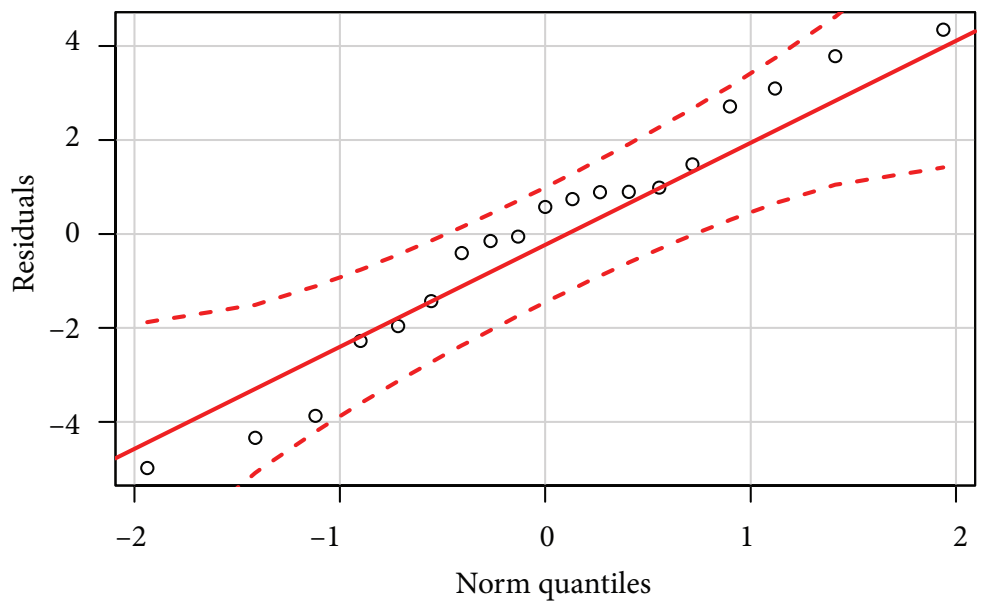

Figure 1. Q - Q plot for a linear regression model (source: own data processing in $\mathrm{R}$ program)

The second assumption is the stability of the model, which is verified by homoscedasticity, i.e. by comparing variance of deviations. If deviations of empirical values from the estimated values occur randomly, that is, they do not tend to cluster, the model is homoscedastic and it fulfils the condition of stability. It is best to see the homoscedasticity of the model from the graphical representation (Figure 2).

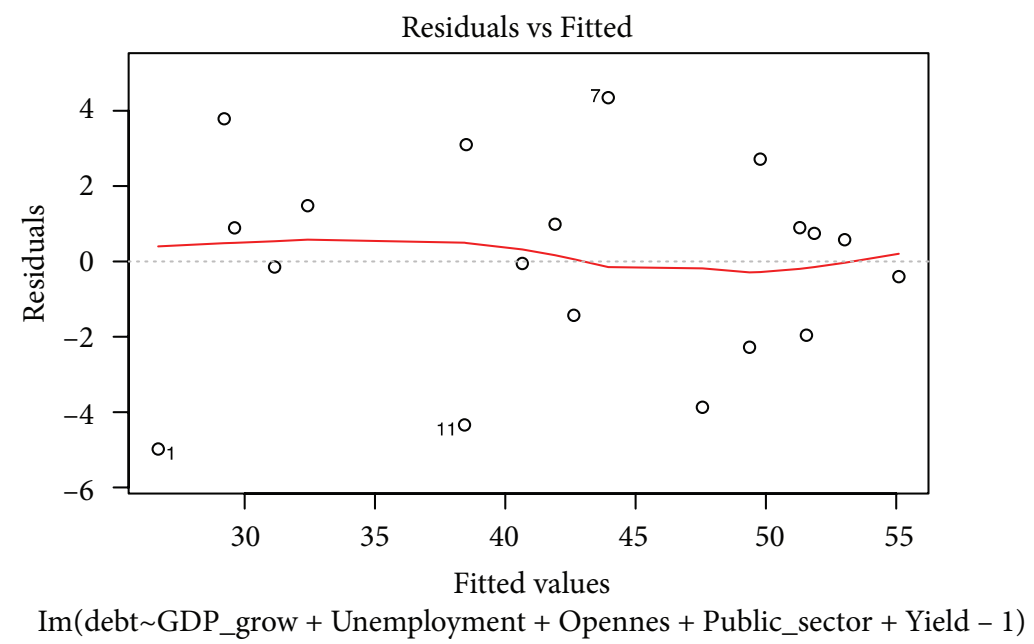

Figure 2. Deviation of empirical and estimated values (source: own data processing in $\mathrm{R}$ program) 
Finally, the last assumption for the use of the linear regression model for prediction, is the value of the coefficient of variance determination, which expresses how many percent of development of the dependent variable, in this case the size of the public debt, the model is able to explain. To verify the value, authors calculated the adjusted $\mathrm{R}$ square, which is adjusted to take into account the number of estimated model parameters and also the number of observations for all variables. For authors' linear model, the adjusted coefficient of variance determination has achieved the value of 0.9952 (Adjusted R - squared of Table 2), which means that the model explains more than $99 \%$ of the changes in public debt.

\section{Prediction of public debt in Slovakia}

After verifying the statistical assumptions that confirmed the possibility of using a linear regression model to predict the development of public debt size, authors calculated the amount of public debt for year 2017. For the calculation, authors have used a linear regression model with five parameters as shown in Table 3.

The value of the public debt as a share of GDP for 2017 was estimated at $46.72 \%$ of GDP. Table 4 displays estimated value of public debt to GDP share, the real value and the difference between them.

Table 3. Values of indicators in linear regression model (source: own data processing in $\mathrm{R}$ program)

\begin{tabular}{|ccccc|}
\hline GDP_growth & Unemployment & Opennes & Public_sector & Yield \\
-2.5895092 & 1.1841952 & 0.1247139 & 0.5623663 & -1.1507661 \\
\hline
\end{tabular}

Table 4. Public debt in 2017 (prediction and real value) (source: own data processing in $\mathrm{R}$ program according to Eurostat, n.d. data)

\begin{tabular}{|cc|}
\hline Prediction of public debt & 0.4672 \\
Actual public debt & 0.518 \\
Difference & 0.0508 \\
\hline
\end{tabular}

Actual debt in the year 2017 reached 51.8\% of GDP. Authors' forecast therefore underestimated the size of the public debt by $5.087 \%$. Figure 3 shows the size of the public debt as a share of GDP in individual years from 1995 to 2017, with the triangle representing prediction for 2017. Given the simplicity of the linear regression model, the deviation of the predicted value of the size of the public debt from the reality in 2017 is relatively small.

\section{Conclusions}

The economic crisis that Slovakia, the countries of the European Union and other economies of the world have undergone, has caused the issue of deficits and public debt to become very topical. Public debt in most countries began to rise sharply during the crisis, bringing about several serious problems. The countries were forced to take measures to reduce them, to restore economic growth and recovery their economies. Although the situation is starting to improve lately, the threat of high public debt is still up to date. 


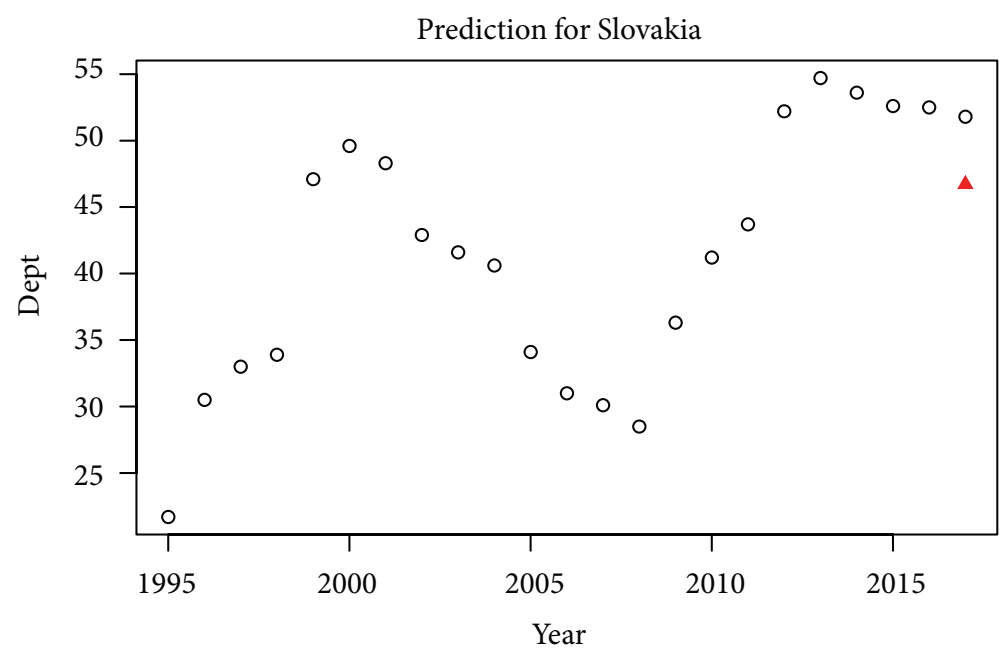

Figure 3. Development of public debt from 1995 to 2017, including prediction for 2017 (source: own data processing in $\mathrm{R}$ program)

There are number of different factors behind the development of public debt, from historical, through political, to economic factors. Given the complexity and range of the issue, from a number of factors influencing public debt in this research, authors have selected only a group of macroeconomic indicators. The focus and main objective of our work was to analyse their impact on public debt, to choose those which influence public debt most significantly and to create a model that could be used to predict further trends of public debt in Slovakia. Authors selected macroeconomic indicators on the basis of the scientific studies and researches carried out in this field, supplemented by own proposals and assumptions. An important selection criterion was that the used indicators represent different areas of macroeconomics.

Specific feature of authors' methodological approach was the chosen analysed period. Despite the fact that some studies focused on longer periods (e.g. Salotti \& Trecroci, 2012; Vezzoli, 2015), authors decided for the years 1995-2016. Using of older data would, in case of Slovakia, be more strongly influenced by historical events, socio-political changes, and economic transition to a market economy. Analysed period is quite short (only 22 years, from which authors excluded years 2007, 2008, 2009, as years most strongly influenced by either maximum economic boom or by economic crisis and recession), and it will be necessary to verify correctness of the final model also in longer period. Authors, however, assume that macroeconomic indicators which influence public debt in Slovakia most significantly in short period will influence public debt also in longer period.

Analysis and modelling of public debt dependencies on the group of macroeconomic indicators resulted in a simple linear regression model. The advantage of the simple model is lower probability of losing information in the statistical processing. However, simplicity can also be a negative element if the variables did not develop standard during the period under review, but for instance, due to external factors, they have had more significant deviations from the normal values. In the model, authors avoided influence of non-standard data by 
excluding years 2007, 2008 and 2009. This analysis shows that the macroeconomic indicators, that most affect the level of public debt, are the growth of the gross domestic product, the unemployment rate, the size of the public sector, the openness of the economy and government bonds yields.

Authors confirmed the quality of the assembled linear regression model by testing the distribution normality and homoscedasticity. In the first case, authors used the Q-Q plot to confirm the distribution normality. The homogeneity of variance was confirmed by graphical depiction of the deviations of empirical and estimated values. Applicability of the linear regression model was also confirmed by the calculation of the adjusted coefficient of variance determination, which showed that the indicators selected by us explained more than 99\% of the changes in public debt. The level of public debt changes explained by the linear regression model is very high. Although the predicted public debt size for 2017 calculated using the linear regression model is underestimated by $5.08 \%$, the deviation from the reality, considering given debt level, is relatively small.

This paper implies that public debt is influenced by many indicators, from which various were already analysed in scientific studies. From all macroeconomic indicators, authors focused on GDP growth, inflation, unemployment, labor productivity, size of public sector, and government bond yields. Besides indicators, standardly used for explaining and predicting public debt, we focused also on the openness of the economy. Authors consider openness of economy an important factor influencing economic situation as well as public debt in small economies, such as Slovakia. The aim of the paper was to identify those macroeconomic indicators which influence most significantly public debt in Slovakia and to elaborate and verify simple model for public debt prediction in Slovakia. Study offers unique approach to identify the most significant indicators from various macroeconomic areas, including openness of economy.

In the research, authors focused primarily on the influence of macroeconomic indicators on public debts. It was confirmed by many studies (e.g. Vučkovic \& Sertic, 2013; Eusepi \& Wagner, 2017) that non-economic factors strongly influenced public debt (however, they were not considering combination of macroeconomic and non-economic factors). Authors consider necessary to include also other factors into the future research and models. Authors consider political factors, political decisions, democratic orientation of the country, eventually other non-macroeconomic factors crucial for obtaining more accurate and significant model.

Results of the research included in this paper can serve as source of information and fundament for public policies actions. Authors confirmed that GDP growth and government bond yields influence public debt in positive way (there is a negative dependence between the GDP growth, increase of government bond yields and public debt growth). On the other side, unemployment rate, openness of economy and extent of the public sector have negative influence on the public debt growth. These information can help to choose appropriate policy actions for reducing public debt in Slovakia and to focus particularly on those macroeconomic indicators which have the most significant influence (positive or negative) on the public debt growth.

There are, however, several limitations of the research and findings. Because of the short existence of independent Slovakia, authors were able to analyse only relatively short period 
(22 years) and to construct and verify model only for this short period. It will be necessary to repeat selection of indicators and construction of the model in regular intervals, to confirm the findings and to identify trends and changes in the public debt development in Slovakia. By using other statistics methods as well as expanding the data set under review, it is possible to achieve greater accuracy of predictions as well as to eliminate some drawbacks and shortcomings of a simple linear regression model. Authors consider necessary to continue with the research and to extend research for more countries. It will be interesting and even necessary to apply similar research and to elaborate model in other V4 countries (Czech Republic, Poland, and Hungary). Because of the common past (part of socialistic block, and necessity of transformation from planned economy to market economy), there could be interesting similarities of the public debt development. On the other side, continuity of the development in other V4 countries is longer than in Slovakia (because of their longer existence as independent states). It can lead to more accurate model and possibility of longerterm predictions in these countries. Also openness of the economy can have significantly different influence on public debt in Slovakia than in other V4 countries. Using data from more countries can help to predict public debt development more accurately by using the panel regression model. It will be also interesting to find out, whether openness of economy is a significant factor influencing public debt also in other small open economies.

\section{Funding}

This work was supported by the Grant Agency VEGA, under grant no. 1/0621/17 "Decisionmaking Process of Slovak Households about Allocation of Time for Paid and Unpaid Work and Household Strategies' Impact on Selected Areas of the Economic Practice" at the Faculty of Economics, Matej Bel University in Slovakia.

\section{Author contributions}

Miroslava Knapková was responsible for data and results interpretation, elaboration of structure of article, description of finding, implications, discussion and for corrections after the review process. Martin Kiaba brought an idea of the paper and wrote the very first draft of analytical part of article. Samuel Hudec was responsible for data analysis.

\section{Disclosure statement}

Authors herewith declare that they do not any competing financial, professional, or personal interests from other parties.

\section{References}

Aizenman, J., \& Marion, N. (2009). Using inflation to erode the U.S. public debt (NBER Working Paper 15562). Cambridge, MA: National Bureau of Economic Research. Retrieved from http://www.nber. org/papers/w15562.pdf https://doi.org/10.3386/w15562 
Akitoby, B., \& Binder, A., \& Komatsuzaki, T. (2017). Inflation and public debt reversals in the G7 countries. Journal of Banking and Financial Economics, 1(7), 28-50.

https://doi.org/10.7172/2353-6845.jbfe.2017.1.2

Ambler, S., \& Bouakez, H., \& Cardia, E. (2017). Does the crowding-in effect of public spending on private consumption undermine neoclassical models? Research in Economics, 71(3), 399-410. https://doi.org/10.1016/j.rie.2017.04.004

Baum, A., Checherita-Westphal, C., \& Rother, P. (2012). Debt and growth: new evidence for the Euro area (ECB Working Paper 1450). Retrieved from https://www.ecb.europa.eu/pub/pdf/scpwps/ecbwp1450.pdf?72bd167ee00401965e42c0cc0a949f78

Berben, R. P., \& Brosens, T. (2007). The impact of government debt on private consumption in OECD countries. Economics Letters, 94(2), 220-225. https://doi.org/10.1016/j.econlet.2006.06.033

Berggren, N., \& Bjornskov, Ch. (2019). Regulation and government debt. Public Choice, 178(1-2), 153178. https://doi.org/10.1007/s11127-018-0621-6

Blavy, R. (2006). Public debt and productivity (IMF Working Paper 235(16), pp. 1-27). https://doi.org/10.5089/9781451864953.001

Bohn, F. (2019). Political instablility and seigniorage: An inseparable couple - or a threesome with debt? Review of International Economics, 27(1), 347-366. https://doi.org/10.1111/roie.12379

Bundesministerium für Wirtschaft und Technologie (2010). Ein neues Verfahren für die wirtschaftspolitische Koordinierung in Europa. Berlin: BMWi.

Caner, M., Grennes, T., \& Koehler-Geib, F. (2010). Finding the tipping point - When sovereign debt turns bad (Policy Research Working Paper 5391, pp. 31-71). The World Bank. https://doi.org/10.1596/1813-9450-5391

Challe, E., Charpe, M., Ernst, E., \& Ragot, X. (2011). Countercyclical unemployment benefits and unemployment fluctuations. International Labour Organization. Retrieved from http://ilo.org/wcmsp5/ groups/public/---dgreports/---inst/documents/genericdocument/wcms_192632.pdf

Checherita-Westphal, C., \& Rother, P. (2012). The impact of high government debt on economic growth and its channels: An empirical investigation for the Euro area. European Economic Review, 56(7), 1392-1405. https://doi.org/10.1016/j.euroecorev.2012.06.007

Chen, C., \& Yao, S., Hu, P., \& Lin, Y. (2017). Optimal government investment and public debt in an economic growth model. China Economic Review, 45, 257-278. https://doi.org/10.1016/j.chieco.2016.08.005

Choa, D., \& Rhee, D. E. (2013). Nonlinear effects of government debt on private consumption: Evidence from OECD countries. Economics Letters, 121(3), 504-507. https://doi.org/10.1016/j.econlet.2013.10.013

Cournède, B. (2010). Gauging the impact of higher capital and oil costs on potential output. (OECD Economic Department Working Papers 789, pp. 1-10).

Csortos, O., \& Szalai, Z. (2014). Early warning indicators: Financial and macroeconomic imbalances in Central and Eastern European Countries (MNB Working Paper 2, pp. 1-35).

Dawood, M., \& Horsewood, N., \& Strobel, F. (2017). Predicting sovereign debt crises: an early warning system approach. Journal of Financial Stability, 28, 16-28. https://doi.org/10.1016/j.jfs.2016.11.008

D'Erasmo, P., \& Mendoza, E. G. (2018). History remembered: Optimal sovereign default on domestic and external debt (NBER Working Paper No 25073). National Bureau of Economic Research. Retrieved from https://www.nber.org/papers/w25073 https://doi.org/10.3386/w25073

Di Bartolomeo, G., Di Pietro, M., Saltari, E., \& Semmler, W. (2018). Public debt stabilization: the relevance of policymakers' time horizons. Public Choice, 177(3-4), 287-299.

https://doi.org/10.1007/s11127-018-0584-7 
Esteve, V., \& Tamarit, C. (2018). Public debt and economic growth in Spain, 1851-2013. Cliometrica, 12(2), 219-249. https://doi.org/10.1007/s11698-017-0159-8

European Central Bank. (2010). Reinforcing economic governance in the Euro Area. Retrieved from http://www.ecb.int/pub/pdf/other/reinforcingeconomicgovernanceintheeuroareaen.pdf

European Commission. (2010). Report on Greek Government. Deficit and debt statistics. Retrieved from https://ec.europa.eu/eurostat/documents/4187653/6404656/COM_2010_report_greek/c8523cfad3c1-4954-8ea1-64bb11e59b3a

Eurostat. (n.d.). Retrieved from https://ec.europa.eu/eurostat/home

Eusepi, G., \& Wagner, R. E. (2017). Public debt: An illusion of democratic political economy. Edward Elgar Publishing. https://doi.org/10.4337/9781786438041

Ferrari, G. (2018). On the optimal management of public debt: A singular stochastic control problem. Siam Journal on Control and Optimization, 56(3), 2036-2073. https://doi.org/10.1137/16M1084870

Furceri, D., \& Mourougane, A. (2010). The effects of fiscal policy on output: A DSGE analysis (OECD Economic Department Working Papers 770, pp. 1-33).

Goedl, M., \& Zwick, Ch. (2018). Assessing the stochastic stability of public debt: the case of Austria. Empirica, 45(3), 559-585. https://doi.org/10.1007/s10663-017-9376-4

Gomez-Puig, M., \& Sosvilla-Rivero, S. (2018). Public debt and economic growth: further evidence for the euro area. Acta Oeconomica, 68(2), 209-229. https://doi.org/10.1556/032.2018.68.2.2

Heise, M. (2011). Notwendigkeit und Ausgestaltung Makroökonomischer Überwachung im Euroraum. Wirtschaftsdienst, 91(1), 22-30. https://doi.org/10.1007/s10273-011-1166-1

Horváthová, L., Horváth, J., Gazda, V., \& Kubák, M. (2012). Fiscal decentralization and public debt in the European Union. Lex Localis, 10(3), 265-276. https://doi.org/10.4335/171

Islami, M., \& Kurz-Kim, J. R. (2014). A single composite financial stress indicator and its real impact in the Euro area. International Journal of Finance \& Economics, 19(3), 204-211.

https://doi.org/10.1002/ijfe.1483

Knedlik, T., \& Schweinitz, G. (2012). Macroeconomic imbalances as indicators for debt crises in Europe. Journal of Common Market Studies, 50(5), 726-745. https://doi.org/10.1111/j.1468-5965.2012.02264.x

Kwon, G., McFarlane, L., \& Robinson, W. (2006). Public debt, money supply, and inflation: A crosscountry study and its application to Jamaica (IMF Working Paper 17 (06/121), pp. 1-39). https://doi.org/10.5089/9781451863819.001

Lammam, C., \& MacIntyre, H. (2016). Public debt a threat to Canada. Winnipeg Free Press, A.9, 1-23.

Mazúrová, B., \& Kollár, J. (2015). The importance of government spending in context of fiscal policy. In Proceedings of the 1st International Conference European Fiscal Dialog 2015: Current Issues of Fiscal Policy (pp. 109-117). Prague: Newton College.

Milesi-Ferretti, G. M., Perotti, R., \& Rostagno, M. (2002). Electoral systems and public spending. Quarterly Journal of Economics, 67(1), 609-657. https://doi.org/10.1162/003355302753650346

Národná stratégia trvalo udržatelného rozvoja. (2001). Retrieved from http://hpur.vlada.gov.sk/data/ files/5636_narodna-strategia-trvalo-udrzatelneho-rozvoja.pdf

Nayak, J. R., \& Pandit, V. (2015). GDP growth and public debt: alternative scenarios. Journal of Economic Policy and Research, 11(1), 84-102. Retrieved from https://search.proquest.com/docview/18 28144665 ? accountid $=17223$

Neck, R., Blueschke, D., \& Weyerstrass, K. (2012). Macroeconomic Policies for Slovenia in the "Great Recession". International Advances in Economic Research, 18(4), 345-366. https://doi.org/10.1007/s11294-012-9376-X

Ono, T., \& Uchida, Y. (2018). Human capital, public debt, and economic growth: A political economy analysis. Journal of Macroeconomics, 57, 1-14. https://doi.org/10.1016/j.jmacro.2018.03.003 
Oulton, N., \& Sebastiá-Barriel, M. (2017). Effects of financial crises on productivity, capital and employment. Review of Income and Wealth, 63, 90-112. https://doi.org/10.1111/roiw.12253

Page, A. (2018). War, public debt and Richard Price's Rational Dissenting radicalism. Historical Research, 91(251), 98-115. https://doi.org/10.1111/1468-2281.12215

Persson, T., Roland, G., \& Tabellini, G. (2007). Electoral rules and government spending in parliamentary democracies. Quarterly Journal of Political Science, 20, 1-34. http://dx.doi.org/10.1561/100.00006019

Pescatori, A., Sandri, D., \& Simon, J. (2014). Debt and growth: Is there a magic threshold? (IMF working paper 14/34, pp. 1-19). https://doi.org/10.5089/9781484306444.001

Poghosyan, T. (2018). How do financial cycles affect public debt cycles? Empirical Economics, 54(2), 425-460. https://doi.org/10.1007/s00181-016-1215-0

Real, A., Katsuyuki, N., \& Tetsuo, O. (2018). Intergenerational policies, public debt, and economic growth: A politico-economic analysis. Journal of Public Economics, 166, 39-52. https://doi.org/10.1016/j.jpubeco.2018.08.006

Reinhart, C. M., \& Rogoff, K. S. (2010). Growth in a time of debt. American Economic Review, 100(2), 573-578. http://dx.doi.org/10.1257/aer.100.2.573

Roubini, N., \& Sachs, J. (1989). Government spending and budget deficits in the industrial countries. Economic Policy, 4(8), 100-132. https://doi.org/10.2307/1344465

Salotti, S., \& Trecroci, C. (2012). Even worse than you thought: The impact of public debt on aggregate investment and productivity. In DEGIT Conference Papers c017_020, DEGIT, Dynamics, Economic Growth, and International Trade. (pp. 1-23). https://doi.org/10.2139/ssrn.2033107

Savona, R., \& Vezzoli, M. (2015). Fitting and forecasting sovereign defaults using multiple risk signals. Oxford Bulletin of Economics and Statistics, 77(1), 66-92. https://doi.org/10.1111/obes.12052

Sinha, P., Arora, V., \& Bansal, V. (2011). Determinants of public debt for middle income and high income group countries using panel data regression (MPRA Paper 32079, pp. 1-28). Retrieved from https:// mpra.ub.uni-muenchen.de/32079/1/MPRA_paper_32079.pdf

Stasavage, D. (2003). Public debt and the Birth of the democratic state: France and Great Britain 16881789. Cambridge University Press. https://doi.org/10.1017/CBO9780511510557

Vučkovic, V., \& Sertic, M. B. (2013). The effect of political institutions on the size of government spending in European Union member states and Croatia. Financial Theory and Practice, 37(2), 161-179. https://doi.org/10.3326/fintp.37.2.2

\section{APPENDIX}

\section{Notations}

Variables and functions

$R^{2}$ - coefficient of determination;

$R_{\text {adj }}^{2}$ - adjusted coefficient of determination;

$n$ - size of the sample;

$k$ - number of explanatory variables;

$y$ - explained variable;

$x_{i}-$ explanatory variables. 